\title{
PERBANYAKAN VEGETATIF TUSAM (Pinus merkusii Jungh et de Vriese) DENGAN TEKNIK CANGKOK
}

\section{VEGETATIVE PROPAGATION OF TUSAM (Pinus merkusii Jungh et de Vriese) GENERATED BY AIR LAYERING METHOD}

\author{
Suryanaji ${ }^{1}$, Purwanto ${ }^{1}$, Arga Pramudita ${ }^{1}$ \\ ${ }^{1)}$ Perhutani Forestry Institute (PeFI). \\ Jalan Wonosari-Batokan. Tromol Pos 6. Cepu. 58302. Indonesia. \\ Email: suryanaji@perhutani.co.id; purwanto412@perhutani.co.id; argap@perhutani.co.id
}

Diterima: 22 Juni 2021, Direvisi: 29 Juni 2021, Disetujui: 29 Juli 2021

DOI: $10.31849 /$ forestra.v16i2.7095

\begin{abstract}
Pinus merkusii is a main species for produce pine resin in Indonesia. Clone of Pinus merkusii on progeny trial establishing by Perhutani has identified can produce high yielderresin up to 100 gr/tree/3 days. Clonal forestry needs applied propagation method that easy dan economically on operational level. One of propagation method selected was by air layering. This research work were to obtained genetic materials and to get information number of live percent of seedling from air layering from high yielder resin Pinus merkusii subline when the mother trees reach 12 years old. The research was conducted in Perum Perhutani KPH Banyumas Barat, RPH Samudra on year 2020 with Completely Randomized Design (CRD). The result of this research showed that rooting ability on Pinus merkusii 12 years old mother trees have signifiant differences between subline. Rooting ability of seedling generated by air layering method were 29\% (subline SG2), 24\% (subline JB2), $18 \%$ (subline SL2) and 11\% (subline SM2) with an average of 18\% and heritability of rooting ability by air layering was 0,44 .
\end{abstract}

Keywords: Pinus merkusii, air layering, subline, high yielder resin

\begin{abstract}
ABSTRAK
Pinus merkusii merupakan jenis penghasil getah pinus yang utama di Indonesia. Beberapa Klon Pinus merkusii pada uji keturunan yang dibangun Perhutani telah diidentifikasi memiliki produktivitas getah yang tinggi. Perhutanan klonal memerlukan metode propagasi vegetatif yang mudah dan ekonomis serta dapat diaplikasikan pada level operasional. Salah satu perbanyakan yang dipilih adalah dengan metode cangkok. Penelitian ini bertujuan koleksi materi genetik dan untuk mengetahui prosen jadi dari beberapa subgalur Pinus merkusii produksi getah banyak (bocor getah) yang berasal ketika tanaman induk sudah berumur 12 tahun. Penelitian dilaksanakan di Perum Perhutani KPH Banyumas Barat, BKPH Lumbir, Resort Pemangkuan Hutan Samudra pada tahun 2020 dengan menggunakan Rancangan Acak Lengkap (RAL). Hasil penelitian menunjukan bahwa kemampuan berakar pada Pinus merkusii umur 12 tahun memiliki perbedaan yang nyata antar sub galur. Kemampuan berakar bibit yang diperoleh dari cangkok masing-masing sub galur adalah $29 \%$
\end{abstract}


(sub galur SG2), 24\% ( sub galur JB2), 18\% (subgalur SL2) dan 11\% (subgalur SM2) dengan rerata keberhasilan sebesar 18\% dan heritabilitas keberhasilan dengan metode cangkok sebesar 0,44.

Kata kunci: Pinus merkusii, cangkok, subgalur, getah banyak

\section{PENDAHULUAN}

Percepatan produksi getah pinus di Perum Perhutani dilakukan dengan berbagai perbaikan di semua aspek. Di level operasional, peningkatan getah dapat dilaksanakan dengan perbaikan sistem manajemen tenaga kerja, sistem insentif dan dari aspek teknis dengan perbaikan teknik penyadapan, alat penyadapan maupun penggunaan stimulansia untuk merangsang aliran getah. Perbaikan produksi getah dengan penggunaan stimulan sampai saat ini merupakan cara yang paling efektif dari aspek produktivitas, namun memiliki resiko kerusakan pada bidang sadapan yang dapat mengakibatkan kematian pohon lebih cepat.

Dari program pemuliaan pohon, Perhutani terus mengembangkan dan menyeleksi klon-klon unggul penghasil getah. Pada skala operasional, produksi getah di Perhutani diperkirakan sebesar 21 gr/phn/3hari (Purwanta et al., 2009). Selanjutnya pemuliaan pinus di Perhutani diselaraskan dengan tujuan peningkatan pada produktivitas getah produksi minimal $50 \mathrm{gr} / \mathrm{phn} / 3$ hari. Pada tegakan konifer, perbanyakan vegetatif genotipe yang superior memberikan manfaat utama untuk mendapatkan genetic gain yang besar, karena akan menghasilkan proporsi variasi genetik yang luas untuk dapat diperoleh pada satu siklus seleksi (Ragonezi et al., 2010).

Perbanyakan vegetatif pada dasarnya dapat diaplikasikan pada semua tanaman berkayu. Pada tanaman buah berbatang kayu, stek batang paling banyak diterapkan untuk proses perbanyakan (Hussain, Assis, Yamamoto, Koyama, \& Roberto, 2014). Salah satu perbanyakan yang banyak digunakan selain stek batang adalah dengan menggunakan cangkok. Cangkok seringkali digunakan karena memiliki tingkat keberhasilan berakar yang relatif tinggi pada tanaman berkayu. Periode pada setiap tahun merupakan faktor yang sangat penting dalam mempengaruhi perakaran cangkok, dan ini berhubungan langsung dengan kondisi fisiologis dari pohon induk dan fase perkembangannya, sehingga akan mempengaruhi produksi substansi pengatur tumbuh (Lins et al., 2015). Hormon yang 
banyak dipakai untuk merangsang akar cangkok pada umumya adalah IBA (Baghel, Raut, \& Vikas, 2016); (Rehman, Awan, Khan, \& Haq, 2013); (Durán-Casas, Suan, Magnitskiy, \& Lancheros, 2013); (Maurya, Lewis, \& Chandler, 2013); Penggunaan IAA (Irawan, Tamin, \& Hardiyanti, 2019) serta kombinasinya kombinasi IBA, NAA dan IAA (Kamila \& Panda, 2019); (Ramírez-Malagón et al., 2014); (Ahmad et al., 2021). Upaya lain meningkatkan keberhasilan perakaran dapat menggunakan fungisida (Washa, Nyomora, \& Lyaruu, 2012). Fungisida mampu mencegah jamur yang menyebabkan busuk pada bagian batang yang terluka (Gortari et al., 2019). Penelitian ini bertujuan koleksi materi genetik dan untuk mengetahui prosen jadi dari beberapa subgalur Pinus merkusii produksi getah banyak (bocor getah) yang berasal ketika tanaman induk sudah berumur 12 tahun.

\section{METODE PENELITIAN}

Penelitian dilaksanakan di RPH Samudra, BKPH Lumbir, KPH Banyumas Barat. Ketinggian tempat berkisar 390 m dpl dengan jenis tanah Latosol coklat. Alat yang digunakan pada penelitian ini adalah pisau untuk mengupas kulit pinus, alat panjat, top soil untuk media tumbuh cangkok, kantong plastik bening untuk membungkus media top soil, tali rafia, polibag, sedangkan bahan-bahan yang digunakan terdiri dari hormon perangsang akar berbentuk pasta, peta pohon uji progeni untuk identifikasi lokasi pohon terseleksi, klon-klon Pinus merkusii terpilih pada lokasi pemapanan tanaman uji umur 12 tahun dengan jarak tanam $4 \mathrm{~m}$ x $3 \mathrm{~m}$, alat tulis dan blangko pengamatan.

Tahap pertama penelitian adalah penandaan pohon-pohon yang sudah diidentifikasi sebagai klon-klon yang memiliki produktivitas getah tinggi. Pohonpohon tersebut selanjutnya dilakukan pemanjatan untuk dilakukan cangkok pada pucuk-pucuk yang masih relatif muda. Diamater pucuk yang dicangkok kurang lebih $1 \mathrm{~cm}$. Jumlah ulangan setiap sub galur berbeda-beda menyesuaikan jumlah klon yang memiliki produktivitas diatas 100 gr/phn/3 hari. Dari setiap ulangan tersebut kemudian dipilih 30 pucuk yang layak untuk dilakukan cangkok. Rancangan yang digunakan adalah Rancangan Acak Lengkap dengan ulangan unbalanced maksimal sebanyak sebanyak 147 pohon 
pada subgalur JB2. Pembuatan cangkok dilakukan dengan perlakuan yang seragam dengan menggunakan hormon berbentuk pasta dengan dosis 20 gram hormon untuk 90 cangkok. Hormon yang digunakan memiliki komposisi kombinasi antara Naftalene acetid acid (NAA), Indole Butyrid acid (IBA), dan Thiram dalam bentuk serbuk yang selanjutnya dibuat pasta. Pembuatan cangkok dilakukan dengan memilih pucuk dengan panjang kurang lebih $40 \mathrm{~cm}$. Pucuk terpilih selanjutnya dilakukan pengelupasan dengan pisau kupas untuk pembersihan kambium serta getah yang melekat. Pada pelukaan bagian atas, dioles dengan menggunakan hormon pasta secara merata melingkar pada bagian calon kalus. Setelah proses ini dilakukan penutupan dengan media yang dibungkus plastik yang pada bagian dalam sudah dilakukan penyobekan agar media topsoil menempel pada luka sayatan. Kemudian media dilekatkan melingkar pada batang dan diikat dengan tali rafia. Setelah cangkok dibuat, selanjutnya ditunggu dalam jangka waktu maksimal 6 bulan sampai terbentuk akar. Jika 6 bulan tidak muncul akar, maka diasumsikan tidak tumbuh/hidup. Keberhasilan cangkok parameternya adalah jika pada saat cangkok dipanen telah memiliki akar dan dalam keadaan hidup.

Data yang dikumpulkan adalah prosen jadi bibit tanaman yang hidup dan sudah berakar, dan dokumentasi penelitian lainnya. Data prosentase hidup selanjutnya dilakukan konversi. Menurut RibeiroOliveira, Santana, Pereira, \& Santos (2018), tranformasi data diperlukan agar analisis data dapat memenuhi asumsi homogenitas, sehingga data dapat dilakukan analisis sidik ragam. Data pada penelitian ini dilakukan dengan rumus tranformasi arcsin sebagai berikut:

Data tranformasi $=\arcsin \sqrt{\text { prosentase }+0,5}$ Analisis sidik ragam menggunakan program SPSS 15.0 dan dengan adanya replikasi data yang unbalanced selanjutnya dianalisis dengan prosedur GLM (General Linear Model). Dari hasil analisis sidik ragam, jika perbedaan yang signifikan selanjutnya dilakukan analisis Post Hoc dengan metode Duncan Multi Range Test (DMRT) pada taraf kepercayaan 95\%. Estimasi heritabilitas dalam arti luas untuk kemampuan berakar dilakukan pendekatan dengan persamaan 
Wahana Forestra: Jurnal Kehutanan Vol. 16 No. 2 Juli 2021

$H^{2}=\sigma^{2} g / \sigma^{2} f$ dimana $\sigma^{2} f=\sigma^{2} g+\sigma^{2} e$

Keterangan : $\mathrm{H} 2=$ heritabilitas; $\sigma^{2} \mathrm{~g}=$ varian genetik $\sigma^{2} \mathrm{f}=$ varian fenotip; $\sigma^{2} \mathrm{e}=$ varian lingkungan (Acquaah, 2012). Penelitian ini dilaksanakan mengikuti tata waktu selama periode tahun 2020 .

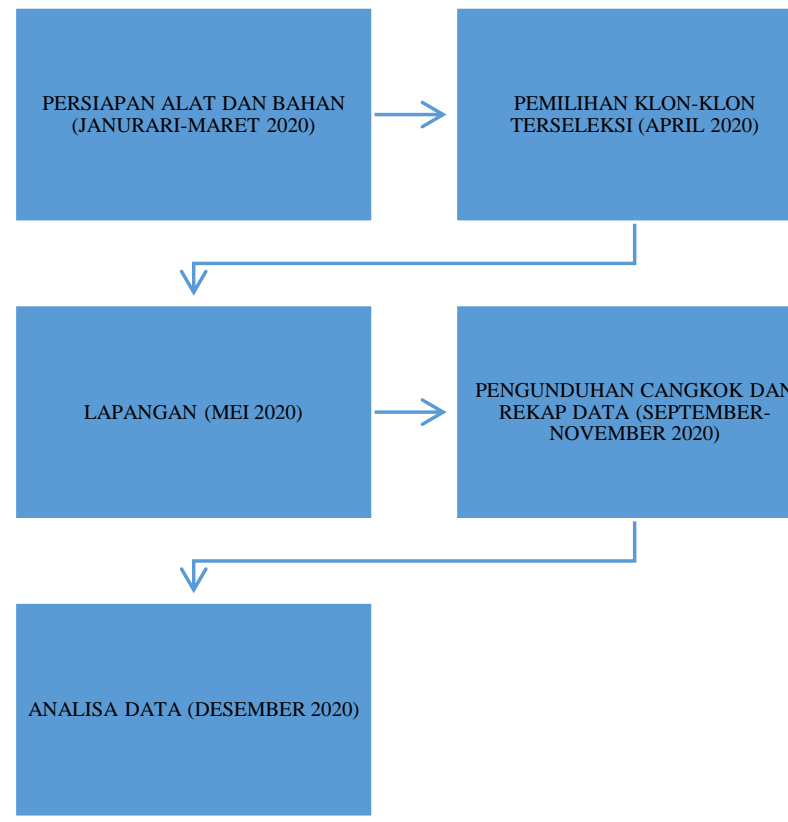

Gambar 1. Alur Waktu Penelitian

\section{HASIL DAN PEMBAHASAN}

Pembuatan cangkok pada tanaman Pinus merkusii sampai saat ini belum lazim dilakukan untuk pembangunan hutan. Beberapa kesulitan yang dihadapi pada pembuatan cangkok adalah kesulitan pemanjatan pada pohon-pohon yang usia diatas 5 tahun, kemampuan sprouting pucuk, dan kemampuan berakar dari pohon.
Pada penelitian ini pengambilan pucuk dilakukan dengan pemanjatan manual. Pada dasarnya penelitian cangkok ini merupakan salah satu komponen dari upaya upaya koleksi materi vegetatif sebagai bahan untuk perhutanan klonal pinus bocor getah. Pembuatan cangkok dimulai bulan Mei 2020 dan dilakukan panen maksimal 6 bulan. Posisi cabang yang dilakukan cangkok dapat dilihat pada gambar berikut.

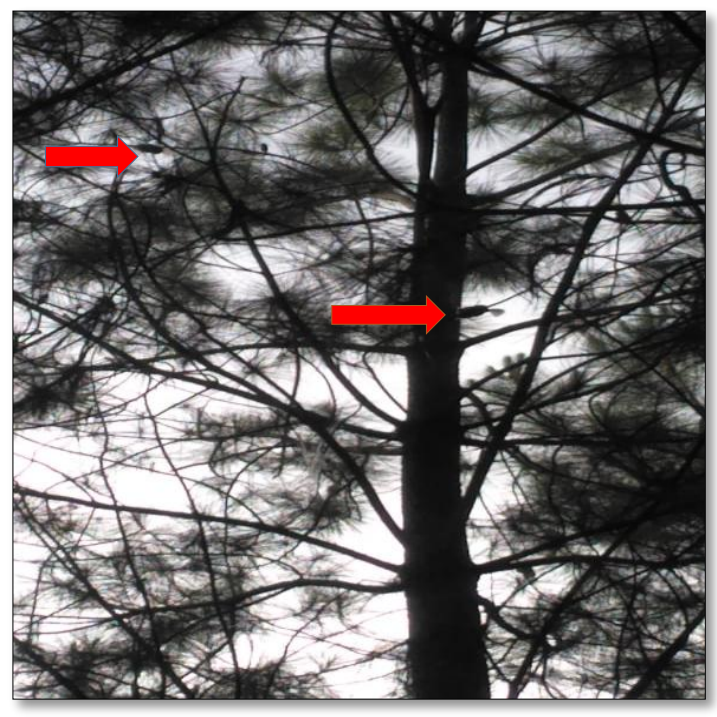

Gambar 1. Letak posisi cangkok

Pemanenan cangkok dilaksanakan dengan memotong cabang tepat dibawah media perakaran sepanjang $2 \mathrm{~cm}$. Sebelum cangkok diunduh, dilakukan pengamatan pada media tumbuhnya terbentuk akar atau tidak. Beberapa cangkok terkadang tetap 
dalam kondisi segar meskipun tidak berakar. Materi dengan kondisi ini diasumsikan tidak berakar. Cangkok yang berhasil hidup dan berakar ditunjukan pada gambar 2.

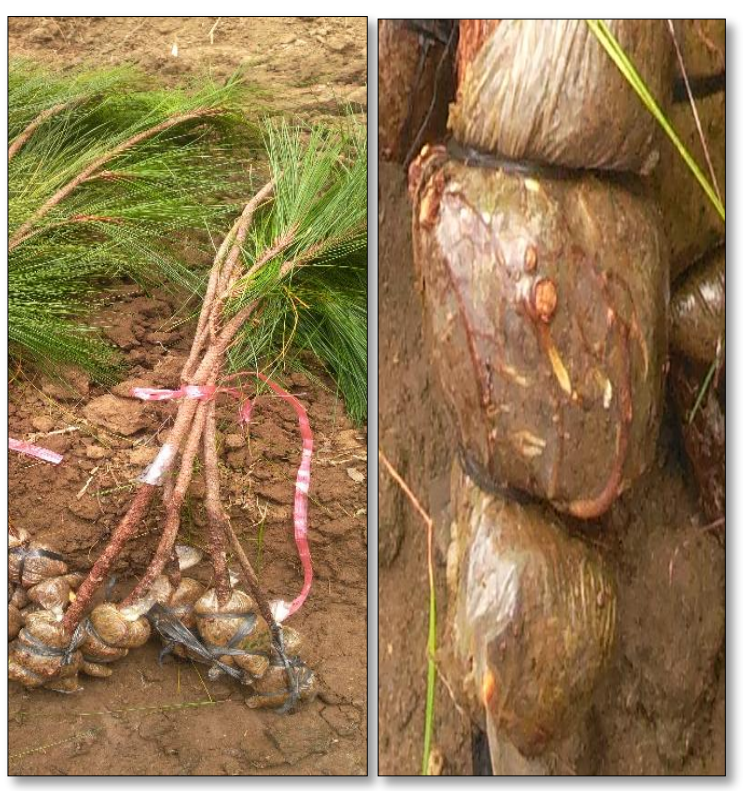

Gambar 2. Cangkok dan perakarannya.

Dari gambar tersebut terlihat bahwa perakaran dapat diamati secara langsung. Penggunaam media yang bening bertujuan untuk mengamati perakaran yang telah muncul untuk menentukan pemanenan. Keberhasilan berakar dalam masing-masing galur memiliki variasi yang cukup beragam.
Secara umum hampir semua galur memiliki beberapa klon yang sama sekali tidak berakar. Sedangkan nilai maksimum yang mampu dicapai oleh masing-masing subgalur adalah sebagai berikut:

Tabel 1. Keberhasilan cangkok maksimum yang mampu dicapai beberapa subgalur

\begin{tabular}{cc}
\hline Sub-galur & $\begin{array}{c}\text { Keberhasilan } \\
\text { maksimum (\%) }\end{array}$ \\
\hline$S G 2$ & $50 \%$ \\
$J B 2$ & $50 \%$ \\
$S L 2$ & $47 \%$ \\
$S M 2$ & $43 \%$ \\
\hline
\end{tabular}

Data tersebut menunjukkan bahwa subgalur SG2 dan JB2 memiliki keberhasilan berakar maksimal 50\% dan yang paling rendah adalah subgalur SM2 dengan keberhasilan maksimum sebesar 43\%. Data individual ini memberikan gambaran bahwa keberhasilan berakar sangat bervariatif didalam galur itu sendiri antara 0-50\%. Untuk mengetahui perbedaan dalam kemampuan berakar antar subgalur selanjutnya dilakukan analisis sidik ragam pada taraf signifikasi 5\%. Hasil analisis selengkapnya pada tabel 2 berikut. 
Tabel 2. Hasil Analisis Sidik Ragam Prosentase Keberhasilan Cangkok

\begin{tabular}{lrrrrr}
\hline Source & \multicolumn{5}{c}{ Mean } \\
Sum of square & Df & Square & \multicolumn{1}{c}{ F } & \multicolumn{1}{c}{ Sig. } \\
\hline Ulangan &, 889 & 146 &, 006 & 18,566 &, 005 \\
Galur &, 086 & 3 &, 029 & 87,168 &, 000 \\
Ulangan * Galur & 1,412 & 146 & .010 & 29.493 &, 002 \\
Error &, 001 & 4 &, 000 & & \\
\hline Total & 135,481 & 300 & & & \\
\hline
\end{tabular}

Dari hasil analisis sidik ragam dapat dikatakan bahwa antar subgalur terdapat perbedaan yang sangat signifikan dalam hal kemampuan berakar. Untuk mengetahui sejauh mana perbedaan antara subgalur tersebut selanjutnya dilakukan uji Duncan dengan hasil sebagaimana pada Tabel 3.

Tabel 3. Hasil Uji Lanjut dengan Duncan Multiple Range Test

\begin{tabular}{lrrrrr}
\hline Galur & N & \multicolumn{3}{c}{ Subset } \\
\hline & & $\mathbf{1}$ & $\mathbf{2}$ & $\mathbf{3}$ & $\mathbf{4}$ \\
\hline SM2 & 151 &, 6427 & & & \\
SL2 & 48 & &, 6627 & & \\
JB2 & 44 & & &, 6816 &, 7168 \\
SG2 & 57 & & & & \\
\hline
\end{tabular}

Hasil uji Duncan menunjukan bahwa dari keempat subgalur secara nyata berbeda antara satu dan lainnya. Analisis ini semakin menunjukkan bahwa subgalur SG2 secara umum memiliki kemampuan berakar yang terbaik. Subgalur SG2 merupakan tanaman - tanaman yang dikoleksi dari kawasan hutan pinus di Jawa Timur. Kemampuan berakar selanjutnya yang kedua dimiliki oleh Subgalur JB2. Subgalur JB2 juga merupakan populasi yang berasal dari kawasan Jawa Timur namun lebih specifik dari kawasan tegakan di Jember. Subgalur SL2 yang terdiri dari populasi yang berasal dari kawasan Sulawesi sedangkan subgalur SM2 berasal dari kawasan Sumedang. 
Kemiripan dengan masa waktu berakar jenis Pinus merkusii, pada tanaman Pinus Taeda, waktu yang diperlukan untuk perakaran antara 4-9 bulan (Barnes, 1973). Pada tanaman Pinus merkusii di Indonesia, proses pembuatan cangkok lebih menguntungkan jika dibuat pada akhir musim kemarau, sehingga setelah beberapa bulan tanaman tersebut berkalus, maka pada musim hujan akar akan berkembang.
Pemanenan sebaiknya segera dilakukan ketika akar sudah tumbuh. Pemanenan yang terlambat sampai musim kemarau memiliki resiko kematian yang tinggi, kecuali dengan media cangkok yang besar. Namun penggunaan media yang besar dapat menyulitkan secara teknis pada pelaksanaan di lapangan. Perbandingan keberhasilan berakar antar sub galur ditunjukan pada gambar 3 berikut ini.

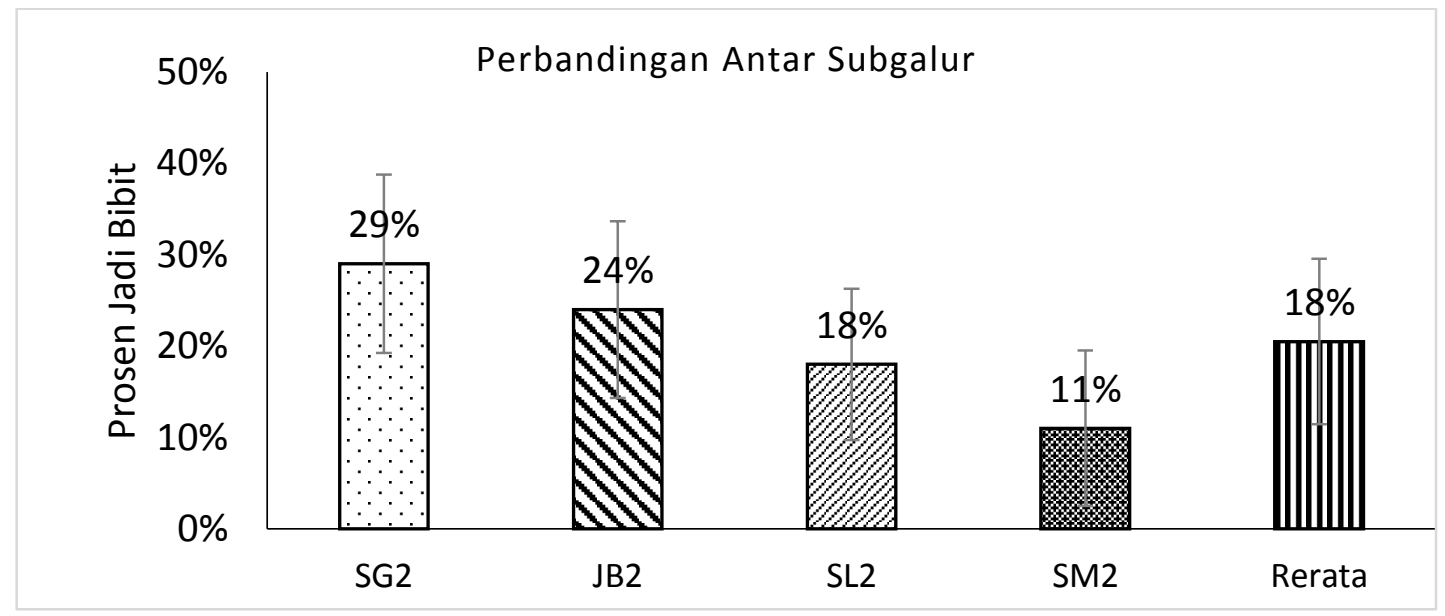

Gambar 3. Grafik perbandingan prosentase keberhasilan cangkok antar subgalur

Perbanyakan vegetatif memiliki nilai yang sangat berharga pada program pemuliaan pohon untuk suatu karakter individual pohon untuk dapat dilakukan multiplikasi tanpa merubah karakter genetiknya. Stek memiliki keuntungan intrinsik dibandingkan dengan grafting, namun dari kebanyakan jenis conifer dan banyak kayu keras sulit untuk berakar (Thomas \& Riker, 1950). Untuk mendapatkan materi stek, diperlukan pembangunan klon superior termasuk memilih pohon plus. Klon-klon ini selanjutnya untuk materi pembangunan Clonal Seed Orchard (CSO) atau kebun pangkas untuk memproduksi dan mensuplai 
materi tanaman yang termuliakan dalam skala luas (Zobel \& Talbert, 1984).

$$
\text { Pada umumnya program }
$$

pemuliaan pinus baik secara komersial maupun benih hasil penyerbukan terkendali berasal dari kebun benih dengan perbanyakan klonal. Kemajuan dalam pemenuhan kebutuhan benih dan untuk membangun populasi hasil breeding tergantung pada keberhasilan teknik yang digunakan. Pada awalnya grafting merupakan metode yang sangat memuaskan untuk perbanyakan spesies pinus, namun menjadi bukti nyata bahwa incompatibility scion dan rootstock menyebabkan kehilangan yang sangat nyata dari produksi ramet pada suatu kebun pangkas. Pada kenyataanya ini akan secara tidak langsung membuat klon tidak bermanfaat didalam kebun benih, dan secara nyata sangat mungkin mustahil perbanyakan suatu ortet dengan grafting (Barnes, 1973)

Alternatif mendapatkan klon dengan stek seringkali tidak berhasil karena pohon plus secara umum memiliki kondisi fisiologis yang sudah tua dan sulit dilakukan induksi akar (Hunt, Trueman, \& Rasmussen, 2011). Peluang ketiga adalah teknik air-layering (cangkok). Membuat cangkok pada pucuk pinus terlihat akan sulit dari aspek teknis disebabkan akses cabang yang sulit dan posisi morfologis materialnya serta status nutrisi pada pucuk yang dicangkok (Sweet, 1964). McAlpine \& Jackson (1956) membuat studi tentang efek maturasi terhadap kerberhasilan cangkok pada tanaman Pinus taeda. Hasil menunjukan bahwa semakin umur meningkat maka keberhasilan cangkok menjadi sangat menurun drastis. Mengingat peluang keberhasilan pada tanaman tanaman pinus dewasa akan mengalami kesulitan karena aspek teknis semisal sulitnya jangkauan cabang dan perawatan, maka peneliti ada yang menyarankan untuk pengambilan materi dari pohon tua menggunakan grafting selanjutnya baru dilakukan dengan cangkok (Sweet, 1964). Menurut Browne, Davidson, \& Gobin, (1996), keberhasilan cangkok pada tanaman pinus banyak dipengaruhi oleh umur tegakan itu sendiri, jarak pucuk dari permukaan tanah dan juga variasi klon. Hal demikian juga terjadi pada tanaman Pinus banksiana dimana perbanyakan vegetatif pada tegakan yang relatif muda lebih mudah daripada yang sudah tua dan pucuk dari bagian yang lebih dekat dengan 
permukaan tanah akan memiliki kemampuan berakar yang lebih tinggi dibandingan dengan dengan bagian atas tajuk. Pengambilan materi genetik ini pada dasarnya lebih pada upaya untuk dikembangkan lagi dengan teknik rejuvenasi dan optimalisasi sprouting sehingga dapat diperbanyak kembali dengan lebih mudah. Semakin meningkat umur, kemampuan untuk membentuk perakaran dari pucuk maupun percabangan menurun dengan tajam. Banyak fenomena dari beberapa penelitian Pinus menunjukan bahwa pada tanaman white pine, kemampuan berakar menurun drastis dengan peningkatan umur. Penggunaan treatment dengan auksin diketahui memang meningkatkan prosen berakar dan kualitas akar namun tidak mampu mengeliminir efek dari umur tegakan induk dimana dia berasal (McAlpine \& Jackson, 1956). Cangkok pada tanaman Pinus merkusii ini memang lebih bertujuan untuk memperoleh materi genetik yang juvenil untuk dapat dilaukukan perbanyakan lebih lanjut.

Derajat urutan juvenil pada suatu tanaman berkayu (pohon) terjadi dari pangkal hingga ujung (Hartmann, Kester, Davies, \& Geneve, 2002). Tunas juvenil kadang ditemukan pada pucuk tunas yang muncul dari akar atau tunggak pohon dari jenis gymnospermae

(Bonga,

Klimaszewska, \& von Aderkas, 2010).

Beberapa penelitian menunjukkan bahwa dengan strategi peremajaan pohon dewasa atau induksi tanaman mundur dari kondisi dewasa ke keadaan muda sangat mungkin meningkatkan kemampuan berakar untuk stek secara signifikan (Liu et al., 2018). Beberapa teknik telah dikembangkan untuk menyegarkan, meremajakan atau menjaga kemudaan tanaman. Tak satu pun dari teknik ini seefektif alami peremajaan dimana bagian tanaman yang paling matang, yaitu alat reproduksi, menghasilkan sebagian besar bagian tanaman remaja, embrio, melalui gametogenesis dan reproduksi seksual (Wendling, Trueman, \& Xavier, 2014). Pada tanaman Lobloly pine, kemampuan berakar menurun sangat tajam ketika usia tegakan indukan mencapai umur 5 tahun. Demikian pula pada tanaman shortleaf pine, pada usia diatas 10 tahun kemampuan berakar menjadi teramat sulit. Sebagai perbandingan, data perbanyakan cangkok pada tegakan Pinus taeda yang penelitiannya dilakukan di hutan milik 
Universitas Georgia pada tahun 1956 menunjukan gejala penurunan kemampuan berakar yang serupa.

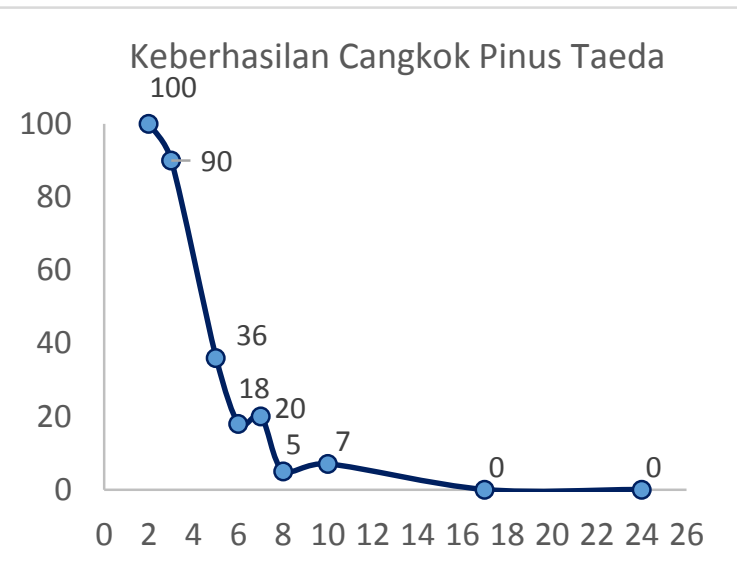

Sumber: Olah data sekunder (McAlpine \& Jackson, 1956)

Gambar 4. Keberhasilan Cangkok Pinus Taeda

Untuk pemenuhan bibit pinus bocor getah dalam skala operasional sampai saat ini beberapa $\mathrm{KPH}$ di perhutani menggunakan strategi cangkok pada tegakan-tegakan muda pinus bocor getah. Dari hasil penelitian, strategi seperti ini terlihat mengalami kesulitan pada capaian prosentase keberhasilan apabila pengambilan materi dari indukan yang berasal dari tegakan-tegakan tua diatas 11 tahun. Pengalaman pada level operasional di lapangan saat ini menunjukan pada tegakan dengan umur maksimal 5 tahun memilik keberhasilan pembuatan cangkok yang bervariasi antara 40-90\%. Perbedaan ini disebabkan antara lain kondisi iklim, ketinggian tempat dan faktor keahlian tenaga kerja. Pencermatan terhadap keberhasilan berakar pada setiap umur tanaman perlu menjadi perhatian. Upaya lain yang perlu dilakukan untuk peningkatan perakaran pada perbanyakan vegetative pinus yang dapat dilakukan adalah dengan menggunakan hormon IBA (Hunt et al., 2011). Penggunaan hormon yang dikombinasikan pada beberapa jenis pinus perlu dicoba pada Pinus merkusii. Hasil penelitian lain, kombinasi antara IBA dan PBZ sangat efektif untuk meningkatkan perakaran Pinus caribaea (Henrique, Campinhos, Ono, \& Pinho, 2006). Kemampuan berakar pada tanaman berkayu secara umum dipengaruhi oleh variasi genetik. Penelitian pada tanaman pinus pun menunjukkan hal yang demikian (Greenwood \& Weir, 1995) dan pada tanaman poplar juga identik (Zalesny, 2003). Pendekatan untuk mengetahui aspek genetik dapat diketahui dengan menghitung nilai heritabilitas. Hasil analisis lanjutan menunjukan bahwa heritabilitas dalam arti luas $\left(\mathrm{H}^{2}\right)$ sebesar 0,44 untuk karakter kemampuan berakar Pinus merkusii yang 
dicerminkan oleh prosen jadi bibit. Nilai heritabilitas dalam rentang ini ini termasuk dalam kriteria sedang karena berada antara 0,2 - 0,5 (Mangoendidjojo, 2003). Dalam kepentingan praktis, penggunaan nilai heritabilitas dalam arti luas akan lebih bermanfaat untuk analisa perbanyakan klonal, sedangkan penentuan nilai heritabilitas dalam arti sempit lebih sering digunakan pada perbanyakan melalui biji (Burdon, 2004). Mengingat nilai heritabilitas ini, maka dalam seleksi klon yang memiliki kemampuan berakar pada program selanjutnya sangat penting untuk memperhatikan klon yang tepat.

\section{KESIMPULAN DAN SARAN}

\section{A. KESIMPULAN}

Dari hasil penelitian dapat disimpulkan bahwa terdapat perbedaan yang signifikan dalam keberhasilan cangkok (persen jadi bibit). Subgalur SG2 memiliki tingkat keberhasilan cangkok yang paling tinggi diikuti oleh subgalur JB2, SL2 dan yang paling rendah adalah subgalur SM2. Rerata keberhasilan cangkok pada tegakan pinus berumur 12 tahun sebesar $18 \%$.

\section{B. SARAN}

Mengingat Perhutani sampai saat ini masih mengandalkan perbanyakan Pinus dengan cangkok maka disarankan untuk mengambil pucuk pada tanaman dengan umur dibawah 12 tahun. Percepatan pemilihan klon sebagai materi kebun pangkas pada masa mendatang perlu seleksi individu-individu terutama pada subgalur SG2 yang memiliki potensi kemampuan berakar paling tinggi.

\section{DAFTAR PUSTAKA}

Acquaah, G. (2012). Principles of Plant Genetics and Breeding (2nd ed). Oxford, UK: Wiley-Blackwell A John Wiley \& Sons, Ltd., Publication.

Ahmad, P. I., Puni, L., Pandey, R., Pala, N. A., Rather, M. M., Rashid, M., \& Malik, A. R. (2021). Influence of different treatments and techniques on rooting behaviour of Rhododendron arboreum Sm. In Indian Himalayas. Acta Ecologica Sinica. https://doi.org/10.1016/j.chnaes.2021.0 1.001

Baghel, M., Raut, U. A., \& Vikas, R. (2016). Effect of IBA Concentrations and Time of Air-layering in Guava cv. L-49. Research Journal of Agricultural Sciences, 7(1), 117-120.

Barnes, R. D. (1973). Air-Layering Of Grafts To Overcome Incompatibility Problems In Propagating Old Pine Trees. N.Z.J. For. Sci, 4(2).

Bonga, J. M., Klimaszewska, K. K., \& von Aderkas, P. (2010). Recalcitrance in clonal propagation, in particular of 
conifers. Plant Cell, Tissue and Organ Culture (PCTOC), 100(3), 241-254. https://doi.org/10.1007/s11240-0099647-2

Browne, R. ., Davidson, C. G., \& Gobin, S. M. (1996). Effects of Crown Position and Plant Age on Rooting of Jack Pine Long Shoot Cuttings. Tree Planter's Notes, 47(3).

Burdon, R. D. (2004). Genetics And Genetic Resources | Quantitative Genetic Principles. In Encyclopedia of Forest Sciences (pp. 182-187). https://doi.org/10.1016/B0-12-1451607/00281-7

Durán-Casas, S., Suan, C. V., Magnitskiy, S., \& Lancheros, H. O. (2013). Evaluation of uva camarona (Macleania rupestris Kunth A.C. Smith) propagation with air layering. Agronomia Colombiana, 31(1).

Gortari, F., Nowosad, M. I. P., Laczeski, M. E., Onetto, A., Cortese, I. J., Castrillo, M. L., ... Niella, F. (2019). Biofertilizers And Biocontrollers As An Alternative To The Use Of Chemical Fertilizers And Fungicides In The Propagation Of Yerba Mate By Mini-Cuttings. Revista Árvore, 43(4). https://doi.org/10.1590/180690882019000400012

Greenwood, M. S., \& Weir, R. J. (1995). Genetic variation in rooting ability of loblolly pine cuttings: effects of auxin and family on rooting by hypocotyl cuttings. Tree Physiology, 15(1), 4145.

https://doi.org/10.1093/treephys/15.1.4 1

Hartmann, H. T., Kester, D. E., Davies, F. T., \& Geneve, R. L. (2002). Plant Propagation: Principles and Practice. Prentice Hall.

Henrique, A., Campinhos, E. N., Ono, E.
O., \& Pinho, S. Z. de. (2006). Effect of plant growth regulators in the rooting of Pinus cuttings. Brazilian Archives of Biology and Technology, 49(2), 189-196.

https://doi.org/10.1590/S1516-

89132006000300002

Hunt, M. A., Trueman, S. J., \& Rasmussen, A. (2011). Indole-3-butyric acid accelerates adventitious root formation and impedes shoot growth of Pinus elliottii var. elliottii $\times P$. caribaea var. hondurensis cuttings. New Forests, 41(3), 349-360. https://doi.org/10.1007/s11056-0109227-7

Hussain, I., Assis, A. M. de, Yamamoto, L. Y., Koyama, R., \& Roberto, S. R. (2014). Indole butyric acid and substrates influence on multiplication of blackberry "Xavante." Ciência Rural, 44(10), 1761-1765. https://doi.org/10.1590/0103-

8478cr20131204

Irawan, B., Tamin, R. P., \& Hardiyanti, R. A. (2019). Effects of Indole Acetic Acid (IAA) and Indole Butyric Acid (IBA) to The Growth and Rooting of Ironwood (Eusideroxylon zwageri Teijsm. \&amp; Binn.) Air Layering. Jurnal Manajemen Hutan Tropika (Journal of Tropical Forest Management), 25(2), 126-134. https://doi.org/10.7226/jtfm.25.2.126

Kamila, P. ., \& Panda, P. . (2019). LargeScale Vegetative Propagation Of Lasiococca Comberi By Air Layering. Journal of Tropical Forest Science, 31(1), 37-42.

Lins, L. C. R., Salomão, L. C. C., Cecon, P. R., \& Siqueira, D. L. De. (2015). The Lychee Tree Propagation By Layering. Revista Brasileira de Fruticultura, $37(2)$, $480-487$. 
https://doi.org/10.1590/0100-2945-

$112 / 14$

Liu, H., Gao, Y., Song, X., Ma, Q., Zhang, J., \& Pei, D. (2018). A novel rejuvenation approach to induce endohormones and improve rhizogenesis in mature Juglans tree. Plant Methods, 14(1), 13. https://doi.org/10.1186/s13007-0180280-0

Mangoendidjojo, W. (2003). Dasar-dasar Pemuliaan Tanaman. Kanisius. Yogyakarta.

Maurya, R. P., Lewis, D. M., \& Chandler, J. S. A. (2013). Studies on the Propagation of Jamaican Ackee (Blighia sapida L.) by Air-layering. HORTSCIENCE, 48(10).

McAlpine, R. G., \& Jackson, L. W. R. (1956). Effect of age on rooting of loblolly pine air layers. Journal of Forestry Research, 57.

Purwanta, S., Suryanaji, \& Sukahardja. (2009). Deteksi Produktivitas dan Kandungan Getah Beberapa Jenis Pinus (Pinus merkusii, Pinus caribaea dan Pinus oocarpa) di RPH Garahan BKPH Sempolan KPH Jember. Buletin Puslitbng Perhutani, 12, 808-815.

Ragonezi, C., Klimaszewska, K., Castro, M. R., Lima, M., de Oliveira, P., \& Zavattieri, M. A. (2010). Adventitious rooting of conifers: influence of physical and chemical factors. Trees, 24(6), 975-992. https://doi.org/10.1007/s00468-0100488-8

Ramírez-Malagón, R., Delgado-Bernal, E., Borodanenko, A., Pérez-Moreno, L., Barrera-Guerra, J. L., Núñez-Palenius, H. G., \& Ochoa-Alejo, N. (2014). Air Layering and Tiny-Air Layering Techniques for Mesquite [ Prosopis laevigata (H. B. ex Willd.) Johnst. M.
C.] Tree Propagation. Arid Land Research and Management, 28(1), 118-128. https://doi.org/10.1080/15324982.2013 .813609

Rehman, M., Awan, A. A., Khan, O., \& Haq, I. (2013). Response Of Olive Cultivars To Air-Layering At Various Timings. Pakistan Journal of Agriscience, 50(4), 555-558.

Ribeiro-Oliveira, J. P., Santana, D. G. de, Pereira, V. J., \& Santos, C. M. dos. (2018). Data transformation: an underestimated tool by inappropriate use. Acta Scientiarum. Agronomy, 40(1), 35300 . https://doi.org/10.4025/actasciagron.v4 $0 \mathrm{i} 1.35300$

Sweet, G. B. 1964: (1964). The effect of physiological age of scion and growth of grafts in Pinus radiata. N.Z. For. Res. Note, 37(8).

Thomas, J. E., \& Riker, A. J. (1950). Progress on rooting cuttings of white pine. J. For., 48, 474-480.

Washa, W., Nyomora, A., \& Lyaruu, H. (2012). Improving propagation success of D. Melanoxylon (African blackwood) in Tanzania (II): Rooting ability of stem and root cuttings of Dalbergia melanoxylon (African blackwood) in response to rooting media sterilization in Tanzania. Tanzania Journal of Science, 38(1).

Wendling, I., Trueman, S. J., \& Xavier, A. (2014). Maturation and related aspects in clonal forestry-part II: reinvigoration, rejuvenation and juvenility maintenance. New Forests, 45(4),

473-486. https://doi.org/10.1007/s11056-0149415-y

Zalesny, R. S. (2003). Genetic and environmental effects on rooting 
ability of dormant unrooted hybrid poplar cuttings (Iowa State University, Digital Repository). https://doi.org/10.31274/rtd-1808132838

Zobel, B., \& Talbert, J. (1984). Applied Forest Tree Improvement. John Wiley \& Sons. 